Sains Malaysiana 48(3)(2019): 669-676

http://dx.doi.org/10.17576/jsm-2019-4803-21

\title{
Influence the Filler Orientation on the Performance of Bipolar Plate
}

(Pengaruh Orientasi Pengisi ke atas Prestasi Plat Dwikutub)

\author{
NABILAH AFIQAH MOHD RadZUAn, AbU BAKAR SUlONG* \& MAHENDRA RAO SOMALU
}

\begin{abstract}
Bipolar plates significantly contribute to the development of the polymer electrolyte membrane (PEM) fuel cells technology due to their ability to produce high electrical conductivity based on the type of materials used. Mismatching of inappropriate materials and manufacture may lead to the inferior performance of PEM fuel cells. Hence, material development was determined crucial to balance the overall performance of PEM fuels including the mechanical properties and electrical conductivity of the materials. Studies on conductive polymer composites (CPCS) offered filler with orientation in terms of filler with aspect ratio and shape as an alternative method to enhance the overall performance of the bipolar plate. Filler orientations permit an excellent conductivity network formation while controlling the filler alignment based on required applications. This paper reviewed various studies of filler orientations including materials used and methods of manufacture of CPC materials for the effective development of bipolar plate. The technique to orientate the filler was highlight in terms of materials processing and its effects on the materials performance.
\end{abstract}

Keywords: Conductive polymer composite; electrical conductivity; orientation

ABSTRAK

Plat dwikutub menyumbang kepada pembangunan teknologi sel fuel polimer elektrolit membran (PEM) memandangkan keupayaannya dalam menghasilkan nilai keberaliran elektrik yang tinggi bersandarkan jenis bahan yang digunakan. Ketidaksepadanan bahan dan proses pembuatan merendahkan prestasi PEM. Oleh itu, penentuan pembangunan bahan amat kritikal dalam memastikan keseimbangan prestasi keseluruhan SFPEM termasuklah sifat mekanik dan nilai keberaliran elektrik bahan. Kajian terhadap bahan komposit polimer pengalir menawarkan orientasi pengisi seperti pengisi bernisbah bidang dan berbentuk sebagai kaedah alternatif dalam meningkatkan prestasi keseluruhan plat dwikutub. Orientasi pengisi membolehkan pembentukan jaringan keberaliran elektrik yang baik dengan mengawal arah penjajaran berdasarkan jenis aplikasi yang ditetapkan. Kertas ini menekankan kepelbagaian kajian orientasi pengisi termasuk bahan serta kaedah pembuatan bahan komposit polimer pengalir dalam pembangunan plat dwikutub yang lebih berkesan. Kaedah bagi mengorientasikan pengisi turut ditekankan daripada segi pemilihan bahan dan kesannya terhadap prestasi bahan.

Kata kunci: Keberaliran elektrik; komposit polimer pengalir; orientasi

\section{INTRODUCTION}

Polymer electrolyte membrane fuel cell (PEMFC) is a potential power source for various applications due to its low operating temperature, high efficiency, high power density and good impermeability (González-Espasandín et al. 2019; Rosli et al. 2018). A significant component of the PEMFC is the bipolar plates which account for $80 \%$ of the total stack weight and $45 \%$ of stack cost (Antunes et al. 2011; Mohd Radzuan et al. 2016). Generally, there are two types of bipolar plates used in PEMFCs including metal based bipolar plate and carbon based bipolar plate (Du et al. 2010; Radzuan et al. 2018). However, the major limitation of metal based bipolar plate is the lack of corrosion resistance which promotes degradation while carbon-based bipolar plate is lack in mechanical properties as the material become more brittle, less durable and more permeable to gases (Du et al. 2010; Hwang et al. 2008; Suherman et al. 2013; Taherian 2014).
There are various materials available to develop the bipolar plate including traditional graphite, metallic alloy and graphite-polymer composite (Antunes et al. 2011; Hwang et al. 2008). However, these materials have a major drawback which deteriorates the performance of bipolar plate as a result of the imbalance between the electrical conductivity and mechanical properties (Antunes et al. 2011). Thus, current research trends tend to use conductive polymer composite (CPC) as an alternative material due to its ability to enhance electrical conductivity while maintaining the mechanical properties of the material (Balogun \& Buchanan 2010; Sulong et al. 2013; Zakaria et al. 2015). CPC materials are obtained by mixing the insulating material such as thermoplastic or thermoset material with conductive fillers such as carbon black, carbon nanotubes (CNTs) and carbon fibre (Antunes et al. 2011; Feller et al. 2002). The unique morphology and structure of the conductive pathways within the composite 
materials are the main parameters that determine the electrical properties of CPCs (Feller et al. 2003). However, due to numerous choices of materials, there are still lots of improvement on the bipolar plate performance are required. The commercial bipolar plate is usually developed using graphite $(\mathrm{G})$ materials which have the disadvantage in brittleness and difficulty in machining (Antunes et al. 2011; Lee et al. 2009; Mathur et al. 2008; Suherman et al. 2013; Taherian 2014). As a result, a thick bipolar plate is produced which in turn increases the weight of fuel cell stack (Antunes et al. 2011; Taherian 2014).

High electrical conductivity is the key requirement for an excellent bipolar plate. The electrical conductivity is usually measured as a through-plane and in-plane electrical conductivity (Mohd Radzuan et al. 2016). However, the obtained electrical conductivity remains inadequate as the through-plane electrical conductivity is generally lower than in-plane electrical conductivity as shown in numerous studies (Suherman et al. 2013a, 2013b; Zakaria et al. 2015). For example, a study using CNTs/G reinforce epoxy (EP) showed that the electrical conductivities of the through-plane and in-plane conductivity were $180 \mathrm{~S} / \mathrm{cm}$ and $65 \mathrm{~S} / \mathrm{cm}$, respectively (Suherman et al.2013). The same trend was also reported using the $\mathrm{CF} / \mathrm{SG} / \mathrm{EP}$ composite materials where the throughplane conductivity $(50.34 \mathrm{~S} / \mathrm{cm})$ was determined lower than in-plane conductivity $(69.79 \mathrm{~S} / \mathrm{cm}$ ) (Zakaria et al. 2015). These results explained the deficiency of the overall performance of the bipolar plate as a result of low through-plane conductivity. Figure 1 illustrates the mechanism of electron flow in the bipolar plate which determined the through-plane and in-plane conductivities of the plate (Suherman et al. 2013a, 2013b). Yet, none of the studies has achieved these conditions due to some deficiency in conductivity network formations.

Several studies suggested that the electrical conductivity of composite materials often affected by the structural properties of the fillers used in the insulating resin matrix including filler aspect ratio, shape factor and fillers orientations (Antunes et al. 2011; Barton et al. 2007; Clingerman et al. 2002). Filler orientations seem to be an alternative way to improve the electrical conductivity of the bipolar plate. For instance, studies based on the multiwalled carbon nano-tubes (MWNTs) showed that the occurrence of network formations at low MWNT content in the bipolar plate due to excellent nanotubes dispersions (Pötschke et al. 2004). Since 1993, Lux has described the importance of filler distributions, orientation and processing technique in the insulating matrix as the orientation of fillers along the basal plane is able to produce higher electrical conductivity in comparison to the perpendicular to basal plane (Kakati et al. 2011; Lux 1993). The properties of graphite and CNTs fillers, which have the high aspect ratio exhibited the anisotropic electrical properties that guarantee the high performance in the parallel axial direction (Fan \& Advani 2005; Kakati et al. 2011, 2009; Qi et al. 2014; Wang \& Ogale 1993). However, fillers not necessary have to be in highly anisotropic conditions as studies using the carbon black $(\mathrm{CB})$ particles reported that the electron tunneling was formed as the $\mathrm{CB}$ tends to aggregate (Feller et al.2003). Yet, the electrical conductivity of the composite is usually lower compared to the filler with anisotropic behavior. These results reported while using the CB particles that eventually decreases the anisotropic of the composite and the overall performance on the composite (Kakati et al. 2011). Moreover, the efficient and accurate predictions of the filler orientations also very useful to control and design the manufacturing process as inhomogeneity of fillers often leads to lower materials performance (Agboola et al. 2012). Hence, these studies focused on the filler which exhibited an aspect ratio such as fibers (short fiber and long fiber) or flake-like in order to orientate and result in improving the electrical conductivity and mechanical properties.

\section{DEVELOPMENT IN THE PROCESSING OF COMPOSITE MATERIALS}

The manufacturing process of the bipolar plate is the most important factors as it affects both mechanical properties and the electrical conductivity of composite materials. These factors related to the filler orientation, dispersion within the polymer matrix and conductivity network formations in composite materials (Antunes et al. 2011; Chua et al. 2013). In the current research trend, compression moulding or injection moulding technique is usually used to fabricate the bipolar plate. Injection moulding process offers high productivity that aid in massive productive rates and cost reductions. However,
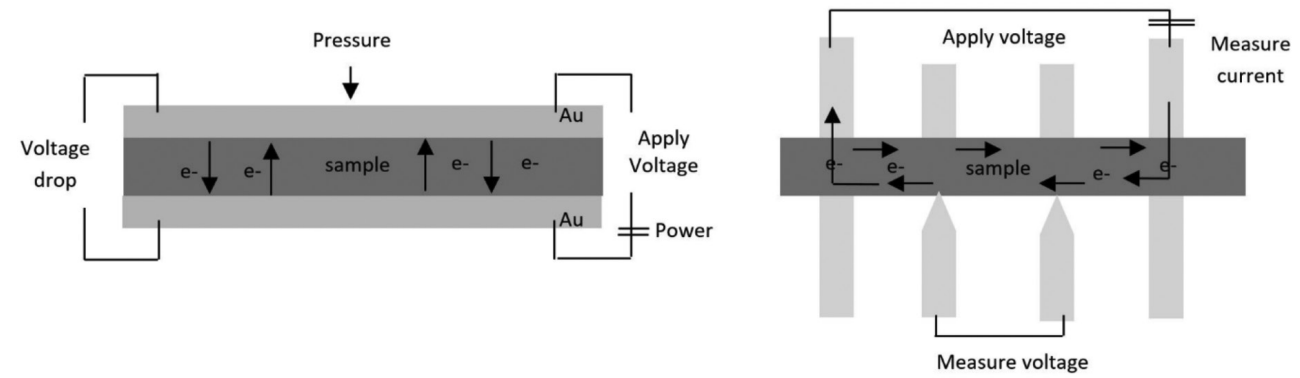

FIGURE 1. Illustrations of (a) through-plane conductivity and (b) in-plane conductivity 
the viscosity of the composites increases due to increase in filler loading which hardens the manufacturing process. Therefore, compression molding seems to be an efficient alternative to produce high CPC materials (Sulong et al. 2013; Taherian 2014). Compression molding enables the fillers to retain within the polymer matrix while producing a laminate structure that maximizes the mechanical strength of the composite materials (Sharma et al. 2009). Studies using the GF/WPVC showed that compression molded sample had better mechanical properties compared to that produced by extrusion process due to low shear stress and low deformations experienced by the composite materials (Tungjitpornkull \& Sombatsompop 2009). The high shear stress resulted in higher fibre breakage which lowers the mechanical strength of composite materials. The severe results obtained by Wang et al. (2011a) using GF/PP composite materials undergoing injection molding process showed that the long fibre (LF) experienced more fibre breakage compared to short fibre. This phenomenon is difficult to compromise as it leads to deterioration in the mechanical properties of composite materials even though shear stress experienced by the fibre enhances the fibre orientations and tensile performance. However, different studies using both long and short fibre of CF/PP composite reported that the longer CF was able to enhance the electrical conductivity of composites due to the earlier formation of conductive pathways (Taipalus et al. 2001). Taipalus et al. (2001) explains in details that the fibre with high aspect ratio was able to form end-to-end contact and led to an excellent conductive network formation. This phenomenon showed that the fibre loading is the key factor in developing excellent conductive pathways since at higher filler loading fibre tends to experience more filler breakage compared to low fibre loading (Antunes et al. 2011; Suherman et al. 2013).

Thus, in order to balance the overall performance of composite materials, current studies applied various manufacturing methods including the method to disperse the fibre within the polymer matrix. For instance, Suherman et al. (2013b) and Kakati et al. (2011, 2009) used several steps to ensure a homogenous mixture including ball milling technique. However, studies reported in 1996 showed that the mechanical properties of composites were improved while using the extrusion process as the fibre tends to orientate its align to the desired orientation (Ausias et al. 1996; Nakayama et al. 2011). This indicated that extrusion is an alternative mixing method which is able to minimize the processing cost and time. In 2008, Barton et al. applied the extrusion process as the premixing process before undergoing the injection molding process on G/CF reinforced liquid crystal polymer (LCP). This demonstrated that the extrusion process is able to obtain a homogenous mixture even with multiple fillers (Barton et al. 2008). Moreover, studies using MWNT/PC showed that the mixing process via extrusion is able to produce a uniformly dispersed mixture (Pötschke et al. 2004). It is crucial to determine the suitable mixing and manufacturing processes to acquire maximum electrical conductivity while maintaining the mechanical properties of composite materials.

\section{FILLERS ORIENTATIONS EFFECTS ON CPC MATERIALS PERFORMANCE}

Previous studies reported that the filler orientations aid in the enhancement of mechanical properties and electrical conductivity at the preferential direction. Studies using GF/ Wood-PVC composites showed that the align fibre tended to have a higher flexural modulus and flexural strength of $20 \%$ increment compared to the random fibre alignment due to the continuity of fibre to bearing of the applied loads. The experiment reported that the fibre which orientates at $0^{\circ}$ experienced the highest tensile strength compared to fibre that orientates at $45^{\circ}$ and $90^{\circ}$ (Tungjitpornkull \& Sombatsompop 2009). Meanwhile, studies using the cotton fibre reinforced geopolymer composites explained that the fibre in horizontal orientations exhibited a higher flexural strength, fracture toughness and compressive strength in contrast to the fibre in vertical orientations as shown in Figure 2 (Alomayri et al. 2014). These are due to the fact that as in vertical orientations, the cotton fibre suffered from detachments and delamination which lowered the composite's strength. Moreover, Alomayri et al. (2014) reported the existence of the crack-bridging in the vertical orientation which further lowered the composite strength. Besides, the fibre orientation along the parallel directions showed excellent anisotropic mechanical properties rather than, in the perpendicular direction when using the graphite composites materials (Panaitescu et al. 2014). These indicated that the fibre orientations are crucial in order to determine optimum mechanical properties which can be developed by using the mixing process including an extrusion process.

Kakati et al. (2011) reported that the electrical conductivity of the composite materials changed by the fibres orientation. These were shown as at higher $\mathrm{CF}$ loading, within $5 \%$ to $9 \%$, the electrical conductivity started to deteriorate due to agglomeration of the fibre in the NG-CB-CF-PF systems (Kakati et al. 2011). These

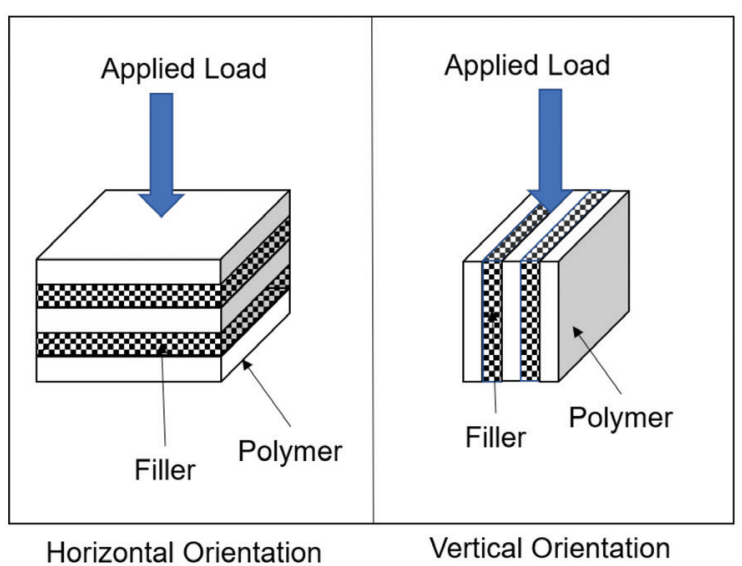

FIGURE 2. Schematic drawing of the cotton fibre orientation with respect to applied load 
were due to the fact that $\mathrm{CF}$ has a higher aspect ratio compared to other fillers in the system as a result of the fillers orientations in the matrix. The same pattern of electrical conductivity enhancement was reported using synthetic graphite (SG) fillers in liquid crystal polymer (LCP) compared to $\mathrm{CF}$ and $\mathrm{CB}$ fillers due to the fact that the fillers with high aspect ratio tended to orientate accordingly within the polymer matrix to provide a good electrical pathway (Barton et al. 2007). The latest research reported that the fillers with high aspect ratio were used as the secondary fillers as their ability to fill the empty space of the primary fillers within the polymer matrix while developing an electrical network simultaneously (Mohd Radzuan et al. 2017a). These showed that the high aspect ratio fillers have the capability to enhance the electrical conductivity of composite materials in many ways. Meanwhile, studies using the MWNTs in polycarbonate (PC) matrix reported that there was no evidence of fibres orientation as MWNT orientated randomly in both perpendicular and parallel to the extrusion directions (Pötschke et al. 2004). Researchers reported that this phenomenon was due to the high aspect ratio and extreme geometry structure of the fibre. Besides, low shear rate and viscosity during the melting and mixing process also the main cause of the fibre to orientate randomly, as low shear stress was transferred onto the fibre. However, these randomly orientated MWNTs seem to be practical in certain applications, in order to enhance the percolation threshold of the composite materials up to 1.5 wt. \%, as WMNTs were dispersed evenly in the polymer matrix (Pötschke et al. 2004). These explained that the fibre orientation has the ability to control the mechanical properties and the electrical conductivity based on the applications needs.

\section{METHODS TO INDUCE FILLERS ORIENTATIONS}

Since 1997, filler orientation in composite materials has been investigated to enhance materials performance. However, studies often focused on mechanical properties rather than the overall performance of the composite materials. Thus, current trends showed that filler orientations are able to boost electrical conductivity while maintaining the mechanical properties of the materials (Mohd Radzuan et al. 2017b). There were a few methods used to induce the fibre into certain orientations including shear rate, die geometries and filler aspect ratio (Fan \& Advani 2005; Kuriger et al. 2002; Taipalus et al. 2001). Fibre aspect ratio often related to the filler distributions within the polymer matrix. At low filler loading, filler aspect ratio is the key of filler distributions affecting the conductivity network formations (Taherian et al. 2013). Moreover, high aspect ratio fillers tended to orientate more compared to low aspect ratio fillers (Taipalus et al. 2001). It has been demonstrated that by introducing a breaker plate as the pre-orientation medium led to higher degrees of fibre orientation compared to traditional slit convergent dies (Hine et al. 1995). In 1996, studies reported that the classical dies, later known as convergent dies produced a longitudinal orientation while divergent dies produced elongational deformations which allow the fibre to orientate to the desired orientations (Ausias et al. 1996). However, near the die walls, the shear deformation force of the fibre to align in longitudinal orientations. These explained the importance of die geometry in order to produce adequate fibre orientations. A study on glass fibre reinforced polypropylene indicated that the introduction of a pre-shearing using a slit die was able to orientate the glass fibre at $0.1 \mathrm{~s}^{-1}$ pre-shearing for $60 \mathrm{~min}$ (Köpplmayr et al. 2013). However, different phenomenon was reported when using series sizes of the die gage on WMNT/vinyl ester composites. Fan and Advani (2005) reported that there are similarities of WMNTs alignment in every microchannel, nanochannel and cross-section of the cylinder despite differing in gauge sizes due to non-Brownian motion effect to randomise the fibre orientations. Tungjitpornkull et al. (2009) demonstrated that the compression molding was able to orientate fibre in $0^{\circ}$ compared to extrusion technique using the twin-screw extruder. The studies reported that the fibre tended to align $0^{\circ}$ while giving maximum mechanical properties (Tungjitpornkull \& Sombatsompop 2009; Yusoff et al. 2010).

Besides, studies using the PP/wood-fibre composites reported that the screw speed of $150 \mathrm{rpm}$ produced higher mechanical properties and narrow size distributions compared to $100 \mathrm{rpm}$ and $200 \mathrm{rpm}$. These are due to the better dispersion of the wood-fibre in the composite materials (Zhang et al. 2012). This strongly explained by the morphology structure of the composite PP/wood-fibre, where the best reaction occurred at $150 \mathrm{rpm}$. Studies using polyethylene glycol as a lubricant able to induce the short fibre into a correct fibre orientation throughout all the die thicknesses influenced by the shear force (Ausias et al. 1996; Fan \& Advani 2005; Köpplmayr et al. 2013; Pötschke et al. 2004). Moreover, Fan and Advani (2005) reported that the orientations of MWNT remain unchanged after applying the shear force for $24 \mathrm{~h}$ suggesting that the shear flow were permanently generated. The shear stress not only does develop better orientations but also affect the fibre microstructure. Studies using the long glass fibre reinforced polypropylene (LFPP) reported that LFPP experienced fibre breakage which deteriorated the mechanical properties including the tensile properties of composite materials (Wang et al. 2011a). Besides, an increase in the generated shear force increased the melt viscosity, which in turn increased the fibre addition and resulted in fibres orientation (Unverfehrt \& Rehage 2015; Wood et al. 2001). However, a composite mixture with high viscosity may lead to difficulties in processing and formation of voids in the final composite materials (Suherman et al. 2013). Huang and Rodrigue (2014) proposed a study on different orientation angles which indicated that at an angle of 00 has the highest shear stress and normal stress compared to $30^{\circ}, 60^{\circ}$ and $90^{\circ}$ of fibre orientations. This demonstrated that the fibre orientation strongly related to shear stress and viscosity of the composite materials. 
TABLE 1. Fibre orientation measuring methods

\begin{tabular}{|c|c|c|c|c|}
\hline Matrix & Filler & $\begin{array}{l}\text { Composite Processing } \\
\text { method }\end{array}$ & Orientation measurement & Reference \\
\hline Polybutadiene (PB) & MWNT & Rheology & $\begin{array}{l}\text { Shear light-scattering/ } \\
\text { microscopy (optical } \\
\text { measurement) }\end{array}$ & (Hobbie et al. 2003) \\
\hline Polypropylene & $\begin{array}{l}\text { Graphite } \\
\text { Carbon black }\end{array}$ & Compression molding & VPSEM & $\begin{array}{l}\text { (Dweiri \& Sahari 2008, } \\
\text { 2007) }\end{array}$ \\
\hline Polypropylene & Short fibre & Extrusion & SEM (photograph) & (Ausias et al. 1996) \\
\hline Phenol formaldehyde & Graphite & Compression molding & SEM (data image processing) & (Kakati et al. 2009) \\
\hline Polycarbonate (PC) & MWNTs & Extrusions & $\begin{array}{l}\text { SEM } \\
\text { AFM } \\
\text { TEM }\end{array}$ & (Pötschke et al. 2004) \\
\hline Vinyl ester & Oxidized MWNT & $\begin{array}{l}\text { Micro and nano-sized } \\
\text { channels }\end{array}$ & $\begin{array}{l}\text { TEM } \\
\text { Second order tensor }\end{array}$ & (Fan \& Advani 2005) \\
\hline Polyetherimide (PEI) & Carbon fibre & $\begin{array}{l}\text { Plain weave (adhesive } \\
\text { wear study) } \\
\text { Compression molding }\end{array}$ & SEM & (Sharma et al. 2009) \\
\hline $\begin{array}{l}\text { Sheet molding } \\
\text { compounds (SMC) }\end{array}$ & Glass fibre & Pyrolysis & $\begin{array}{l}\text { Transmission of visible light } \\
\text { X-ray imaging }\end{array}$ & $\begin{array}{l}\text { (Massardier-Nageotte et } \\
\text { al. 2003) }\end{array}$ \\
\hline Polypropylene & $\begin{array}{l}\text { Glass fibre (short fibre } \\
\text { and long fibre) }\end{array}$ & Compression molding & $\begin{array}{l}\text { X-ray computed tomography } \\
(\mathrm{X}-\mathrm{CT})\end{array}$ & (Köpplmayr et al. 2013) \\
\hline $\begin{array}{l}\text { Poly-ester } \\
\text { Poly-epoxy }\end{array}$ & Short carbon fibre & Compression molding & SEM & (Feller et al. 2002) \\
\hline Polyacrylamide & Short glass fibre & - & $\begin{array}{l}\text { SEM (2D-image analysis) } \\
\text { Fibre orientation distribution } \\
\text { (FOD) }\end{array}$ & (Eberhardt et al. 2001) \\
\hline Isophthalic polyester & Glass fibre & $\begin{array}{l}\text { Twisted fibre yarns } \\
\text { (stitching) }\end{array}$ & SEM & $\begin{array}{l}\text { (Solaimurugan \& } \\
\text { Velmurugan 2008) }\end{array}$ \\
\hline Polymers & Short fibre & - & $\begin{array}{l}\text { Fibre length distribution (FLD) } \\
\text { Fibre orientation distribution } \\
\text { (FOD) }\end{array}$ & $\begin{array}{l}\text { (Fu \& Lauke 1996)the } \\
\text { most probable length } \\
\text { (mode length }\end{array}$ \\
\hline $\begin{array}{l}\text { Isotactic } \\
\text { polypropylene }\end{array}$ & Glass fibre & $\begin{array}{l}\text { Extrusions } \\
\text { Injection molding }\end{array}$ & $\begin{array}{l}\text { Optical microscope (OM) } \\
\text { observation } \\
\text { SEM } \\
\text { Micro-FTIR }\end{array}$ & (Wang et al. 2011a) \\
\hline $\begin{array}{l}\text { Wood/poly(vinyl } \\
\text { chloride) }\end{array}$ & E-glass fibre & $\begin{array}{l}\text { Extrusions } \\
\text { Compression molding }\end{array}$ & SEM & $\begin{array}{l}\text { (Tungjitpornkull \& } \\
\text { Sombatsompop 2009) }\end{array}$ \\
\hline Rubber & MWNTs & $\begin{array}{l}\text { Mechanical mixing } \\
\text { Extrusions }\end{array}$ & $\begin{array}{l}\text { FESEM } \\
\text { WAXD }\end{array}$ & (Kim et al. 2006) \\
\hline Thermoplastic & Short fibre & Injection molding & Second order orientation tensor & (Agboola et al. 2012) \\
\hline Polypropylene & Glass fibre & Extrusions & $\begin{array}{l}\text { Transputer controlled image } \\
\text { analysis }\end{array}$ & (Hine et al. 1995) \\
\hline Epoxy & Milled carbon fibre & $\begin{array}{l}\text { Mechanical mixing } \\
\text { Compression molding }\end{array}$ & SEM & (Zakaria et al. 2015) \\
\hline $\begin{array}{l}\text { Nylon } 6,6 \\
\text { Polycarbonate }\end{array}$ & Carbon fiber & $\begin{array}{l}\text { Extrusions } \\
\text { Injection molding }\end{array}$ & Electrical conductivity model & (Clingerman et al. 2002) \\
\hline $\begin{array}{l}\text { Vectra liquid } \\
\text { crystal polymer } \\
\text { (LCP) }\end{array}$ & Carbon fibre & $\begin{array}{l}\text { Extrusions } \\
\text { Injection molding }\end{array}$ & Optical microscope (OM) & (Wang et al. 2011b) \\
\hline Geopolymer matrix & Cotton fabric & Layer & SEM & (Alomayri et al. 2014) \\
\hline Polypropylene & $\begin{array}{l}\text { Single } \\
\text { wall carbon nanotube } \\
\text { (SWCNT) }\end{array}$ & Tensile stress-stain & $\begin{array}{l}\text { Finite element method } \\
\text { (PATRAN) }\end{array}$ & $\begin{array}{l}\text { (Huang \& Rodrigue } \\
\text { 2014) }\end{array}$ \\
\hline
\end{tabular}




\section{MEASURING THE FILLER ORIENTATIONS}

Measuring the filler orientation is very critical as studies showed that the angle of filler orientation was used in predicting the electrical conductivity of composite materials (Mohd Radzuan et al. 2017b; Taipalus et al. 2001). There are various methods available in measuring the filler orientations in composite materials including direct methods and indirect methods. Direct methods such as SEM, FESEM, AFM, X-CT and more are usually used to visualise the fibre orientations especially for micron size fibres as these are the easiest methods to determine the morphology changes in composite materials (Fan \& Advani 2005; Wang et al. 2011a). For instance, Potschke et al. (2004) used the direct methods of SEM, TEM and AFM to observe the fibre alignment in cross-section area, perpendicular and parallel to extrusion direction. In additions, the dispersion of fibre in the nanofibre materials is usually observed using TEM and FESEM. In this observation, the sample is sliced into a thin film (Kim et al. 2006; Massardier-Nageotte et al. 2003; Xiao et al. 2007). On the other hand, Dweri and Sahari (2008, 2007) used the digital image analysis (MatLab) in cooperating with the direct method of VPSEM to measure the electrical conductivity of the composite materials. This indicates that the variety of direct methods can be used to observe the filler orientations in the composite materials. Details of fibre orientation measuring methods are summarized in Table 1.

Meanwhile, the indirect method seems to be an effective method to quantify the amount of fibre alignment produced and to determine the fibre misalignment in the composite materials (Kuriger et al. 2002). X-ray diffraction (XRD) is used extensively for this purpose where the graphitic plane azimuthal diffraction is measured in degrees and used to characterize the fibre orientation. For instance, the fibre alignment was reported as a vapor grew carbon in the preferred direction $\left(0^{\circ}\right)$. It is critical to note that the intensity of the diffraction pattern at high angles is generally very low while the intensity at $0^{\circ}$ is generally very high as shown in a few studies (Kuriger et al. 2002, 2001). In addition, several studies investigated the fibre orientation behavior in composite materials using the wide-angle X-ray diffraction (WAXD) (Kim et al. 2006; Wang et al. 2011b). For example, Kim et al. (2006) determined that the CNTs were aligned in the $\mathrm{x}$-direction as expected when measured using this method. Moreover, WAXD is able to determine the degree of orientation at different CNT loading. For instance, at $5 \mathrm{wt} . \%$. the degree of orientation is lower compared to $30 \mathrm{wt} . \%$. This behavior is due to the fact that at higher filler loading a better network of conductivity was formed resulting from better CNT orientation within the polymer matrix. This demonstrated that the selection of a technique for measuring the fibre orientation is very crucial for effective investigation of the composite materials.

\section{CONCLUSION}

The development of conductive polymer composite (CPC) materials is very important due to the fact that these materials directly influenced the performance of PEM fuel cell. Fibre orientations are the key factor to enhance both the mechanical properties and electrical conductivity of CPC materials. The extrusion process is the best method to induce the fibre into the desired orientations. Based on the discussion previously, the extrusion process is able to induce orientations as it possesses an adequate shear rate and controllable die geometries. Meanwhile, the scanning electron microscope is a common method in determining the fibre orientation compared to indirect methods.

\section{ACKNOWLEDGEMENTS}

The authors gratefully thank the Center for Research and Instrumentation (CRIM), Universiti Kebangsaan Malaysia for the financial support to complete this study under grant number MI-2017-004. The author(s) declared no potential conflicts of interest with respect to the research, authorship, and/or publication of this article.

\section{REFERENCES}

Agboola, B.O., Jack, D.A. \& Montgomery-Smith, S. 2012. Effectiveness of recent fiber-interaction diffusion models for orientation and the part stiffness predictions in injection molded short-fiber reinforced composites. Composites Part A: Applied Science and Manufacturing 43(11): 1959-1970.

Alomayri, T., Shaikh, F.U.A. \& Low, I.M. 2014. Effect of fabric orientation on mechanical properties of cotton fabric reinforced geopolymer composites. Materials \& Design 57: 360-365.

Antunes, R.A., de Oliveira, M.C.L., Ett, G. \& Ett, V. 2011. Carbon materials in composite bipolar plates for polymer electrolyte membrane fuel cells: A review of the main challenges to improve electrical performance. Journal of Power Sources 196(6): 2945-2961.

Ausias, G., Jarrin, J. \& Vincent, M. 1996. Optimization of the tube-extrusion die for short-fiber-filled polymers. Composites Science and Technology 56(7): 719-724.

Balogun, Y.A. \& Buchanan, R.C. 2010. Enhanced percolative properties from partial solubility dispersion of filler phase in conducting polymer composites (CPCs). Composites Science and Technology 70(6): 892-900.

Barton, R.L., Keith, J.M. \& King, J.A. 2008. Electrical conductivity modeling of multiple carbon fillers in liquid crystal polymer composites for fuel cell bipolar plate applications. J. New Mater. Electrochem. Syst. 11(3): 181.

Barton, R.L., Keith, J.M. \& King, J.A. 2007. Development and modeling of electrically conductive carbon filled liquid crystal polymer composites for fuel cell bipolar plate applications. Journal of New Materials for Electrochemical Systems 10(4): 225.

Chua, M.I.H., Sulong, A.B., Abdullah, M.F. \& Muhamad, N. 2013. Optimization of injection molding and solvent debinding parameters of stainless steel powder (SS316L) based feedstock for metal injection molding. Sains Malaysiana 42(12): 1743-1750. 
Clingerman, M.L., King, J.A., Schulz, K.H. \& Meyers, J.D. 2002. Evaluation of electrical conductivity models for conductive polymer composites. Journal of Applied Polymer Science 83(6): 1341-1356.

Du, C., Ming, P., Hou, M., Fu, J., Fu, Y., Luo, X., Shen, Q., Shao, Z. \& Yi, B. 2010. The preparation technique optimization of epoxy/compressed expanded graphite composite bipolar plates for proton exchange membrane fuel cells. Journal of Power Sources 195(16): 5312-5319.

Dweiri, R. \& Sahari, J. 2008. Microstructural image analysis and structure-electrical conductivity relationship of singleand multiple-filler conductive composites. Composites Science and Technology 68(7-8): 1679-1687.

Dweiri, R. \& Sahari, J. 2007. Computer simulation of electrical conductivity of graphite-based polypropylene composites based on digital image analysis. Journal of Materials Science 42(24): 10098-10102.

Eberhardt, C., Clarke, A., Vincent, M., Giround, T. \& Flouret, S. 2001. Fibre-orientation measurements in short-glass-fibre composites - II: A quantitative error estimate of the 2D image analysis technique. Composites Science and Technology 61: 1961-1974.

Fan, Z. \& Advani, S.G. 2005. Characterization of orientation state of carbon nanotubes in shear flow. Polymer 46(14): $5232-5240$.

Feller, J.F., Chauvelon, P., Linossier, I. \& Glouannec, P. 2003. Characterization of electrical and thermal properties of extruded tapes of thermoplastic conductive polymer composites (CPC). Polymer Testing 22(7): 831-837.

Feller, J.F., Linossier, I. \& Grohens, Y. 2002. Conductive polymer composites: Comparative study of poly(ester)short carbon fibres and poly(epoxy)-short carbon fibres mechanical and electrical properties. Materials Letters 57(1): 64-71.

Fu, S.Y. \& Lauke, B. 1996. Effects of fiber length and fiber orientation distributions on the tensile strength of short-fiberreinforced polymers. Composites Science and Technology 56: 1179-1190.

González-Espasandín, Ó., Leo, T.J., Raso, M.A. \& Navarro, E. 2019. Direct methanol fuel cell (DMFC) and H2 proton exchange membrane fuel (PEMFC/H2) cell performance under atmospheric flight conditions of unmanned aerial vehicles. Renewable Energy 130: 762-773.

Hine, P.J., Davidson, N., Duckett, R.A. \& Ward, I.M. 1995. Measuring the fibre orientation and modelling the elastic properties of injection-moulded long-glass-fibre-reinforced nylon. Composites Science and Technology 53(2): 125-131.

Hobbie, E.K., Wang, H., Kim, H., Lin-Gibson, S. \& Grulke, E.A. 2003. Orientation of carbon nanotubes in a sheared polymer melt. Physical Fluids 15: 1196-1202.

Huang, J. \& Rodrigue, D. 2014. The effect of carbon nanotube orientation and content on the mechanical properties of polypropylene based composites. Materials \& Design 55: 653-663.

Hwang, I.U., Yu, H.N., Kim, S.S., Lee, D.G., Suh, J.D., Lee, S.H., Ahn, B.K., Kim, S.H. \& Lim, T.W. 2008. Bipolar plate made of carbon fiber epoxy composite for polymer electrolyte membrane fuel cells. Journal of Power Sources 184(1): 90-94.

Kakati, B.K., Sathiyamoorthy, D. \& Verma, A. 2011. Semiempirical modeling of electrical conductivity for composite bipolar plate with multiple reinforcements. International Journal of Hydrogen Energy 36(22): 14851-14857.
Kakati, B.K., Yamsani, V.K., Dhathathreyan, K.S., Sathiyamoorthy, D. \& Verma, A. 2009. The electrical conductivity of a composite bipolar plate for fuel cell applications. Carbon 47(10): 2413-2418.

Kim, Y.A., Hayashi, T., Endo, M., Gotoh, Y., Wada, N. \& Seiyama, J. 2006. Fabrication of aligned carbon nanotubefilled rubber composite. Scripta Materialia 54(1): 31-35.

Köpplmayr, T., Milosavljevic, I., Aigner, M., Hasslacher, R., Plank, B., Salaberger, D. \& Miethlinger, J. 2013. Influence of fiber orientation and length distribution on the rheological characterization of glass-fiber-filled polypropylene. Polymer Testing 32(3): 535-544.

Kuriger, R.J., Alam, M.K. \& Anderson, D.P. 2001. Strength prediction of partially aligned discontinuous fiber-reinforced composites. Journal of Materials Research 16(1): 226-232.

Kuriger, R.J., Alam, M.K., Anderson, D.P. \& Jacobsen, R.L. 2002. Processing and characterization of aligned vapor grown carbon fiber reinforced polypropylene. Composites Part A: Applied Science and Manufacturing 33(1): 53-62.

Lee, J.H., Jang, Y.K., Hong, C.E., Kim, N.H., Li, P. \& Lee, H.K. 2009. Effect of carbon fillers on properties of polymer composite bipolar plates of fuel cells. Journal of Power Sources 193(2): 523-529.

Lux, F. 1993. Models proposed to explain the electrical conductivity of mixtures made of conductive and insulating materials. Journal of Materials Science 28(2): 285-301.

Massardier-Nageotte, V., Maazouz, A., Peix, G. \& Bres, S. 2003. Methodologies for the characterisation of glass fibre orientation and distribution in large components moulded from sheet molding compounds (SMC). Polymer Testing 22(8): 867-873.

Mathur, R.B., Dhakate, S.R., Gupta, D.K., Dhami, T.L. \& Aggarwal, R.K. 2008. Effect of different carbon fillers on the properties of graphite composite bipolar plate. Journal of Materials Processing Technology 203(1-3): 184-192.

Mohd Radzuan, N.A., Sulong, A.B. \& Sahari, J. 2017a. A review of electrical conductivity models for conductive polymer composite. International Journal of Hydrogen Energy 42(14): 9262-9273.

Mohd Radzuan, N.A., Yusuf Zakaria, M., Sulong, A.B. \& Sahari, J. 2017b. The effect of milled carbon fibre filler on electrical conductivity in highly conductive polymer composites. Composites Part B: Engineering 110: 153-160.

Mohd Radzuan, N.A., Sulong, A.B.A.B., Rao Somalu, M., Radzuan, N.A.M., Sulong, A.B.A.B. \& Somalu, M.R. 2016. Optimization of milled carbon fibre extrusion and polypropylene process for conductive polymer composite. Sains Malaysiana 45(12): 1913-1921.

Nakayama, Y., Takeda, E., Shigeishi, T., Tomiyama, H. \& Kajiwara, T. 2011. Melt-mixing by novel pitched-tip kneading disks in a co-rotating twin-screw extruder. Chemical Engineering Science 66(1): 103-110.

Panaitescu, D.M., Gabor, R.A., Nicolae, C.A., Ghiurea, M., Mihailescu, M. \& Grigorescu, R.M. 2014. Influence of melt processing induced orientation on the morphology and mechanical properties of poly(styrene-b-ethylene/butyleneb-styrene) block copolymers and their composites with graphite. Materials \& Design 64(0): 694-705.

Pötschke, P., Bhattacharyya, A.R. \& Janke, A. 2004. Melt mixing of polycarbonate with multiwalled carbon nanotubes: Microscopic studies on the state of dispersion. European Polymer Journal 40(1): 137-148.

Qi, L., Ju, L. \& Zhou, J. 2014. Tensile properties of 2D-Cf/Mg composite fabricated by liquid-solid extrusion following 
vacuum pressure infiltration. Procedia Engineering 81: 1577-1582.

Radzuan, N.A.M., Sulong, A.B. \& Somalu, M.R. 2018. Effects of die configuration on the electrical conductivity of polypropylene reinforced milled carbon fibers: An application on a bipolar plate. Polymers 10(5): 558.

Rosli, R.E., Sulong, A.B., Wan Daud, W.R., Zulkifley, M.A., Rosli, M.I., Majlan, E.H., Haque, M.A. \& M. Radzuan, N.A. 2018. The design and development of an HT-PEMFC test cell and test station. International Journal of Hydrogen Energy https://doi.org/10.1016/j.ijhydene.2018.01.174.

Sharma, M., Rao, I.M. \& Bijwe, J. 2009. Influence of orientation of long fibers in carbon fiber-polyetherimide composites on mechanical and tribological properties. Wear 267(5-8): 839845.

Solaimurugan, S. \& Velmurugan, R. 2008. Influence of in-plane fibre orientation on mode I interlaminar fracture toughness of stitched glass/polyester composites. Composites Science and Technology 68: 1742-1752.

Suherman, H., Sahari, J. \& Sulong, A.B. 2013a. Effect of small-sized conductive filler on the properties of an epoxy composite for a bipolar plate in a PEMFC. Ceramics International 39(6): 7159-7166.

Suherman, H., Sulong, A.B. \& Sahari, J. 2013b. Effect of the compression molding parameters on the in-plane and through-plane conductivity of carbon nanotubes/ graphite/epoxy nanocomposites as bipolar plate material for a polymer electrolyte membrane fuel cell. Ceramics International 39(2): 1277-1284.

Sulong, A.B., Ramli, M.I., Hau, S.L., Sahari, J., Muhamad, N. \& Suherman, H. 2013. Rheological and mechanical properties of carbon nanotube/Graphite/SS316L/ polypropylene nanocomposite for a conductive polymer composite. Composites Part B: Engineering 50: 54-61.

Taherian, R. 2014. A review of composite and metallic bipolar plates in proton exchange membrane fuel cell: Materials, fabrication, and material selection. Journal of Power Sources 265: 370-390.

Taherian, R., Hadianfard, M.J. \& Golikand, A.N. 2013. Manufacture of a polymer-based carbon nanocomposite as bipolar plate of proton exchange membrane fuel cells. Materials \& Design 49: 242-251.

Taipalus, R., Harmia, T., Zhang, M.Q. \& Friedrich, K. 2001. The electrical conductivity of carbon-fibre-reinforced polypropylene/polyaniline complex-blends: Experimental characterisation and modelling. Composites Science and Technology 61(6): 801-814.

Tungjitpornkull, S. \& Sombatsompop, N. 2009. Processing technique and fiber orientation angle affecting the mechanical properties of E-glass fiber reinforced wood/PVC composites. Journal of Materials Processing Technology 209(6): 3079-3088.

Unverfehrt, A. \& Rehage, H. 2015. Deformation, orientation and bursting of microcapsules in simple shear flow: Wrinkling processes, tumbling and swinging motions. Procedia IUTAM 16: 12-21.
Wang, J., Geng, C., Luo, F., Liu, Y., Wang, K., Fu, Q. \& He, B. 2011a. Shear induced fiber orientation, fiber breakage and matrix molecular orientation in long glass fiber reinforced polypropylene composites. Materials Science and Engineering: A 528(7-8): 3169-3176.

Wang, Z., Fan, X., Wang, K., Deng, H., Chen, F. \& Fu, Q. 2011 b. Fabrication of polypropylene/carbon nanotubes composites via a sequential process of (rotating solid-state mixing)plus-(melt extrusion). Composites Science and Technology 71(11): 1397-1403.

Wang, S.F. \& Ogale, A.A. 1993. Simulation of percolation behavior of anisotropic short-fiber composites with a continuum model and non-cubic control geometry. Composites Science and Technology 46(4): 389-398.

Wood, J.R., Zhao, Q. \& Wagner, H.D. 2001. Orientation of carbon nanotubes in polymers and its detection by Raman spectroscopy. Composites Part A: Applied Science and Manufacturing 32(3-4): 391-399.

Xiao, K.Q., Zhang, L.C. \& Zarudi, I. 2007. Mechanical and rheological properties of carbon nanotube-reinforced polyethylene composites. Composites Science and Technology 67(2): 177-182.

Yusoff, M., Zuhri, M., Salit, M.S., Ismail, N. \& Wirawan, R. 2010. Mechanical properties of short random oil palm fibre reinforced epoxy composites. Sains Malaysiana 39(1): 8792

Zakaria, M.Y., Sulong, A.B., Sahari, J. \& Suherman, H. 2015. Effect of the addition of milled carbon fiber as a secondary filler on the electrical conductivity of graphite/epoxy composites for electrical conductive material. Composites Part B: Engineering 83: 75-80.

Zhang, Z.X., Gao, C., Xin, Z.X. \& Kim, J.K. 2012. Effects of extruder parameters and silica on physico-mechanical and foaming properties of $\mathrm{PP} /$ wood-fiber composites. Composites Part B: Engineering 43(4): 2047-2057.

Nabilah Afiqah Mohd Radzuan, Abu Bakar Sulong*

\& Mahendra Rao Somalu

Fuel Cell Institute

Universiti Kebangsaan Malaysia

43600 UKM Bangi, Selangor Darul Ehsan

Malaysia

Abu Bakar Sulong*

Centre for Materials Engineering and Smart Manufacturing

Mechanical Engineering Programme

Faculty of Engineering and Built Environment

Universiti Kebangsaan Malaysia

43600 UKM Bangi, Selangor Darul Ehsan

Malaysia

*Corresponding author; email: abubakar@ukm.edu.my

Received: 13 September 2018

Accepted: 23 December 2018 